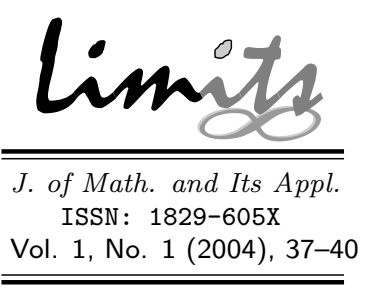

\title{
Pemodelan Kualitas Air Tanah
}

\author{
Suharmadi \\ Jurusan Matematika \\ Institut Teknologi Sepuluh Nopember, Surabaya
}

\begin{abstract}
Abstrak
Pemodelan Kualitas Air Tanah bertujuan untuk mengidentifikasi hal-hal penting seperti, sumber kontaminasi, pengembangan spatial kontaminasi tersebut, dampaknya kontaminasi dimasa depan serta strategi penganggulangan kontaminasi. Model yang dapat merepresentasikan karakteristik transportasi kontaminan dan interaksi kimiawi kontaminan akan dkembangkan. Pengembangan model dilakukan secara bertahap, yaitu, pengembangan model konseptual, mengekspresikan model konseptual kebentuk ekspresi matematika, menentukan solusi analitik atau atau numerik dari model serta melakukan verifikasi model dengan data.
\end{abstract}

Kata kunci: model air tanah, reduksi kontaminasi, strategi reduksi

\section{Pendahuluan}

Kontaminasi pada air tanah baik pada masa lalu maupun dewasa ini, merupakan masalah utama. Penerapan praktek pertanian intensif telah menyebabkan naiknya level 'nitrat', 'pestisida' dan 'herbisida' pada air tanah. Meningkatnya buangan air dari industri (industrial waste) dan buangan sampah rumah tangga, sampah rumah sakit, sampah dari pasar, hotel dan restauran juga memberi kontribusi pada peningkatan kontaminasi air tanah (A.James, 1978). Tujuan dari penelitian ini adalah mereduksi kontaminasi pada air tanah terutama yang berada disekitar tempat pembuangan akhir sampah (TPA).

Tidak seperti pada air permukaan (surface water), air tanah bergeraknya lamban. Diamnya air tanah pada suatu kantong-kantong air dapat berlangsung tahunan, akibatnya kontaminasi pada 'aquifer system' dapat berlangsung dan tidak terdeteksi pada periode yang lama sekali dan menyebabkan penurunan kualitas air tanah secara ekstensif( A. James 1993) Yang perlu di identifikasi pada air tanah yang terkontaminasi adalah hal-hal sebagai berikut: a. Sumber kontaminasi

b. Pengembangan secara spatial kontaminasi tersebut

c. Dampak pada masa depan pada air tanah

d. Strategi penanggulangan kontaminasi dan biaya yang diperlukan.

Model yang dapat menguraikan karakteristik transportasi kontaminasi air tanah dan interaksi kimiawi dari kontaminan dapat digunakan untuk menyelesaikan keempat masalah tersebut diatas terdapat empat tahapan untuk mengembangkan model seperti itu, yaitu: Pengembangan model konseptual, Mengekspresikan model konseptual kedalam bentuk model matematika, solusi analitik atau numerik dari model matematika dan Validasi dari model dengan menggunakan data (Thoman, R.V., 1994). Pengembangan aspek matematika dan numerik model kualitas air tanah adalah fokus tahap utama dari penelitian ini. Meskipun demikian, pentingnya tahap konseptual model sampai dengan pengembangan final dari model kualitas tidak dapat di- 
abaikan. Konseptual model memuat asumsiasumsi penyederhanaan yang digunakan untuk mendefinisikan model matematika. Jadi konseptual model merupakan penghubung utama antara model matematika dan 'sistem aquifer'. Hampir semua sumber air tanah tidak dapat dilihat secara langsung. Struktur dari formasi aquifer, sifat-sifat hidrolika dan distribusi pola aliran air tanah seringkali baru diinferensi dari data distribusi "sparsely." Hanya dengan pengembangan model konseptual yang benar dapat diperoleh model kualitas air tanah yang memuaskan.

\section{Persamaan Gerakan Air Tanah}

Flux air tanah pada aquifer secara umum diberikan oleh Darcy's Law sebagai berikut:

$$
q_{i}=-\frac{k_{i j}}{\mu}\left(\frac{\partial P}{\partial x_{j}}-\rho g_{i}\right)
$$

dimana: $q_{i}$ adalah komponen ke- $i$ dari 'spesific discharge', $q$; $k_{i j}$ adalah komponen ke- $i j$ tensor intrinsil permeability; $\mu$ adalah viscositas fluida; $P$ adalah tekanan fluida; $\rho$ adalah densitas fluida; $g_{i}$ adalah komponen ke- $i$ dari percepatan gravitasi.

Pada kasus dimana densitas air tanah dianggap konstant, Darcy's Law direduksi menjadi:

$$
q_{i}=-K_{i j} \frac{\partial \phi}{\partial X_{i}}
$$

dimana $K_{i j}=K_{i j} \rho q / \mu$ adalah komponen ke$i j$ dari tensor 'hydraulic conductivity' dan $\phi=$ $P / \rho q+z$ adalah hydraulic head.

Hydraulic conductivity pada suatu titik didalam aquifer diperoleh sebagai rata-rata REV (representative elementary volume) yang dipusatkan pada titik tersebut. Ukuran REV dipilih sedemikian hingga perubahan kecil yang terjadi tidak mengakibatkan perubahan significant pada magnitude dari sifat-sifat Aquifer (Hipel W.Keith, 1994)

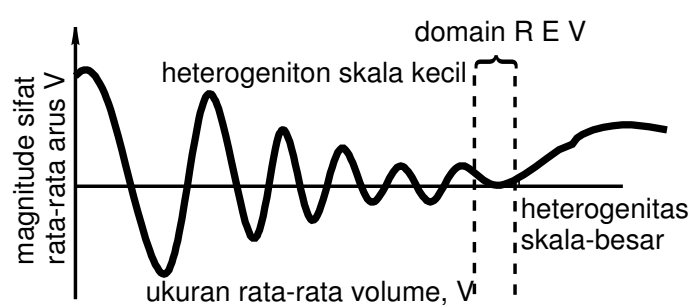

Gambar 1: Rata-rata perubahan gerak
Rata-rata perubahan gerak masa air tanah terhadap perubahan tekanan diberikan dengan koefisien storage, $S_{p}$,

$$
S_{p}=\frac{\partial M}{\partial P}
$$

dimana $M$ adalah massa air tanah per unit volume batuan (rock). Bila densitas air tanah dianggap konstan, formula diberikan oleh specific storativity,

$$
S_{s}=\frac{1}{\rho} \frac{\partial M}{\partial \phi}
$$

yang merupakan perubahan volume air tanah per unit volume dari bantuan, per unit penambahan pada hydraulic head. Keseimbangan massa air tanah pada titik $P$, dalam aquifer didefinisikan dengan menggunakan pendekatan volume control.

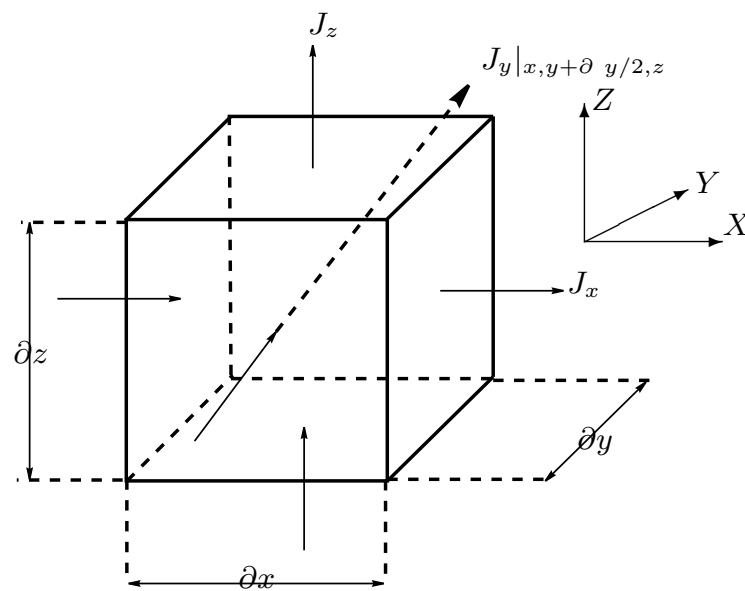

Gambar 2: Kontrol Volume

Vektor $J$ dengan komponen $J_{x}, J_{r}$, dan $J_{z}$ menunjukkan flux massa (yaitu massa air tanah yang melintasi unit area aquiter pada satu unit waktu), bila $\partial M$ adalah penambahan $M$ pada waktu $\partial t$, maka penambahan "net" pada massa air pada volume control pal waktu $\partial t$ adalah $\partial M, \partial x \partial y \partial z$, dengan mempertimbangkan flux massa yang melintasi enam permukaan volume control, diperoleh

$$
\begin{array}{r}
\partial M \partial x \partial y \partial z=\left\{\frac{J_{x}\left|\frac{x-\partial x}{2, y, z}-J_{x}\right| \frac{x+\partial x}{2, y, z}}{\partial x}\right. \\
+\frac{J_{y}\left|\frac{x, y-\partial y}{2, z}-J_{y}\right| \frac{x, y+\partial y}{2, z}}{\partial y} \\
\left.+\frac{J_{z}\left|\frac{x, y, z-\partial z}{2}-J_{z}\right| \frac{x, y, z+\partial z}{2}}{\partial z}\right\}
\end{array}
$$


dimana $J_{x \mid x, y, z}$ adalah flux massa yang dihitung pada titik $(x, y, z)$. Bila persamaan (5) dibagi dengan $\partial t, \partial x, \partial y$ dan $\partial z$ serta diambil limitnya untuk $\partial t, \partial x, \partial y$ dan $\partial z$ dan mendekati nol, diperoleh

$$
\frac{\partial M}{\partial t}=\left\{\frac{\partial J_{x}}{\partial x}+\frac{\partial J_{y}}{\partial y}+\frac{\partial J_{z}}{\partial z}\right\}
$$

yang dapat ditulis dalam bentuk :

$$
\frac{\partial M}{\partial t}=\frac{\partial J_{i}}{\partial X_{i}}
$$

Persamaan (7) menyatakan bahwa rata-rata perubahan massa per unit volume aquifer sama dengan minus divergen flux massa. Hasil ini akan digunakan untuk mengembangkan model matematik transport kontaminasi. Persamaan keseimbangan massa air dapat diperoleh dari tekanan air $\rho$ atau dari potensial hydraulic $\phi$. Dari (3) dapat dilihat bahwa:

$$
\frac{\partial M}{\partial t}=S_{P} \frac{\partial P}{\partial t}
$$

Karena flux massa $J=\rho q$, Persamaan (1), (7) dan (8) dapat dikombinasi dan menghasilkan

$$
S_{P} \frac{\partial P}{\partial X_{i}}\left\{\rho \frac{K_{i j}}{\mu}\left(\frac{\partial P}{\partial X_{j}}-\rho q_{i}\right)\right\}
$$

Dengan cara yang sama dapat diperoleh persamaan keseimbangan massa yang diekspresikan dengan potensial hydraulic, $\phi$

$$
S_{P} \frac{\partial \phi}{\partial t}=\frac{\partial}{\partial X_{i}}\left(K_{i j} \frac{\partial \phi}{\partial X_{j}}\right)
$$

$P$ dan $\phi$ adalah state variabel dari persamaan karena merupakan karakter distribusi baik untuk aliran (flow) dan komponen storage dari equifer. Dengan catatan bahwa koefisienkoefisien persamaan ditentukan secara apriori.

\section{Pendekatan Hidraulic Pe- modelan Aquiter}

Pengembangan persamaan dua dimensi aliran air tambak pada titik $P(x, y)$ dapat dilakukan melalui dua jalur. Jalur pertama adalah dengan mengintegral persamaan 3-dimensi aliran air tanah (10) atau arah vertikal. Jalan kedua adalah melalui pendekatan volume control (Hipel W. Keith, 1994).

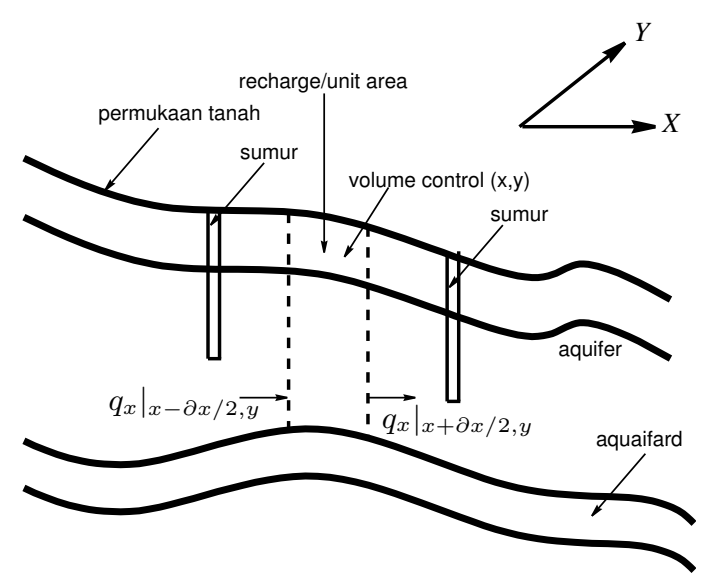

Gambar 3: Skema Cross Section aquifer

Dengan asumsi bahwa density konstan, maka net volumetine in flow (air yang masuk persatuan volume) ke volume control yang berpusat di $P$ dari Gambar 3, diberikan oleh persamaan:

$$
\partial v \partial x \partial y=
$$

dimana $V$ adalah volume air tanah yang disimpan per unit area aquifer; $Q_{x}$ dan $Q_{r}$ adalah komponen vertikal integrasi flux horizontal; $q_{v}$ adalah flux yang melintasi dasar quifer; $W$ adalah net recharge aquifer per unit area; $P_{K}$ adalah abstraction rate dari sumur pada lokasi $\left(X_{K}, Y_{K}\right) ; A_{K}$ adalah area cross sectional dari sumur; $I_{K}(x, y)$ adalah fungsi indikator $(=1$ bila $(x, y)$ pada sumur $\left(X_{K}, Y_{K}\right),=0$ untuk lainnya).

Bila persamaan dibagi dengan $\delta t, \delta x$ dan $\delta y$ kemudian diambil limitnya untuk $\delta t, \delta x$ dan $\delta y$ mendekati nol diperoleh:

$$
\frac{\partial V}{\partial t}=-\frac{\partial Q_{i}}{\partial X_{i}}+q_{V}+W-\sum_{k=1}^{N_{\text {sumur }}} \frac{P_{K}}{A_{K}} I_{K}(x, y)
$$

Flux kolumetric $Q$ dapat diganti dengan ekuivalen Parcian

$$
Q_{i}=-T_{i j} \frac{\partial h}{\partial x_{j}}
$$

dimana $T_{i j}$ adalah komponen ke- $i j$ dari tensor transmissivity dan $h$ adalah elevasi air diatas datum.

Bila hydraulic conductivity dianggap uniform atas kedalaman, maka $T_{i j}$ dapat didefinisikan sebagai berikut:

$$
T_{i j}=K_{i j}(h-b)
$$

dimana $K_{i j}$ adalah komponen horizontal ke-ij dari tensor hydraulic conductivity dan $(h-b)$ 
adalah 'saturated thickness aquifer'. Ratarata perubahan penyimpangan (storage) pada aquifer diberikan oleh

$$
\frac{\partial V}{\partial t}=S \frac{\partial h}{\partial t}
$$

dimana $S=S_{\varepsilon}(h-b)+S_{V}$ adalah koefisien penyimpanan; $S_{\varepsilon}$ adalah storatinity spesifik aquifer; $S_{V}$ adalah spesifik field aquifer.

Dengan mengkombinasi persamaan (12), (13), (14) dan (15) diperoleh formula yang dikenal dengan persamaan "Boussinesq"

$$
\begin{array}{r}
\frac{\partial}{\partial X_{i}}\left(K_{i j}(h-b) \frac{\partial h}{\partial X_{j}}\right)+q_{V}+W \\
-\sum_{k=1}^{N_{\text {sumur }}} \frac{P_{K}}{A_{K}}\left(x_{1}, x_{2}\right)=S \frac{\partial h}{\partial t}
\end{array}
$$

dimana $H_{B}$ adalah fixed head distribution pada boundary. Fixed flux didefinisikan sebagai normal garis boundary, dan dinotasikan sebagai

$$
Q_{n}=Q_{B}(x, y), \quad \text { pada } B
$$

dimana $Q_{n}$ adalah flux normal pada boundary per unit lebar equifer.

Setelah persamaan keseimbangan umum, syarat batas, dan nilai awal didefinisikan, maka yang diperlukan selanjutnya adalah distribusi dari setiap parameter model (yaitu, koefisien storage, hydraulic conductivity dan batasbatas aquifer) pada domain aquifer pada periode waktu tertentu. Bila semua informasi telah lengkap, maka mathematica modelnya sudah terdefinisi dengan lengkap.

\section{Pernyataan Matematika Masalah Aliran Air Tanah}

\section{Kondisi awal}

Pada $t=0$, distribusi awal atas domain aquifer adalah

$$
h(x, y, 0)=H_{0}(x, y)
$$

dimana $H_{0}(x, y)$ adalah initial head distribution.

\section{Kondisi Batas Lateral}

Boundary Condition paling sederhana yang dapat digunakan adalah: (i) fix head atau (ii) fixed flux.

Fixed head dinotasikan pada garis batas , $B$, dengan

$$
h(x, y, t)=H_{B}(x, y), \quad \text { pada } B
$$

\section{Daftar Pustaka}

[1] A. James, An Introduction to Water Quality Modelling, Department of Civil Engineering University of Newcastle upon Tyne, UK, 1993.

[2] A. James, Mathematical Models in Water Pollution Control, University of Newcastle upon Tyne, UK, 1978.

[3] Thomann, R.V., Systems Analysis and Water Quality Management, Mc Brain-Hill Book Company, 1974.

[4] Hipel W. Keith, Stochastic and Statistical Methods in Hydrology, Kluwer Academic Publishers, 1994. 